\title{
KINETICS OF BIOLOGICALLY ACTIVE COMPOUND EXTRACTION FROM HOPS STROBILES EXTRACTION CAKE
}

\author{
Inessa Pavliuk ${ }^{1, *}$, Vasyl Dyachok², Volodymyr Novikov², Nataliya Ilkiv²
}

https://doi.org/10.23939/chcht11.04.487

\begin{abstract}
Kinetics of flavonoids extraction from hops strobiles extraction cake is investigated, total value of mass-transfer resistance is determinate, taking into consideration anatomic features of plant raw material, especially cellular and intercellular environment existence. Validity of proposed mathematical tools technique for evaluation of main kinetic constant of process is confirmed. Obtained result can be applied for equipment calculation in the design of process flow charts of cellular structure solid bodies.
\end{abstract}

Keywords: hops strobiles, extraction cake, kinetics of extraction, diffusion coefficient, mass transfer coefficient.

\section{Introduction}

In continuation of the topic of extraction of cellular structure solid bodies it is important to study not only body internal volume processes, but also the ones in basic volume of extraction solvent, especially when it comes to maceration [1, 2]. Maceration, as one of extraction methods, retains its relevance because of its guaranty of preservation of biologic activity of all components of extracted material. The last extraction stage is mass transfer from the material surface to extract. In case of extraction by maceration method it is impossible to disregard resistance of boundary diffusion layer. Third conditional environment/mileu appears and its volume is determinate by porosity of plant material layer, especially extraction cake. Although extraction solvent is in quiescence state under the particle surface of solid phase, some convection displacements of extraction solvent caused by such physical-chemical parameters as temperature, viscosity, density of solvent, will still be present, but will not influence significantly the maceration process in general.

\footnotetext{
${ }^{1}$ State Scientific-Research Control Institute of Veterinary Medicinal Products and Feed Additives

11, Donetska St., 79019 Lviv, Ukraine

${ }^{2}$ Lviv Polytechnic National University,

12, S. Bandery St., 79013 Lviv, Ukraine

ipavluk@gmail.com

(c) Pavliuk I., Dyachok V., Novikov V., Ilkiv N., 2017
}

We studied hops strobiles extraction cake extraction process after drug product producing; as it turned out a lot of biologically active compounds (BAC) are left in extraction cake. Hops strobiles extraction cake, a manufacturing side-product, is represented by indiscrete moisture mass of fragmented material. It contains 0.2 $1.7 \%$ of essential oil, $5-20 \%$ of bitter principles (humulone, lupulone, etc.), choline, asparagine, organic acids, leucoanthocyanidins and compounds with estrogen effects. Hop polyphenols are mainly flavonoids $\left(\mathrm{C}_{6}-\mathrm{C}_{3}-\right.$ C6) [3-5].

Flavonoids were chosen as main group of biologically active compounds (BAC) for extraction, regarding their significant quantity in wastes of medicinal plant raw material (MPM) and in consideration of preservation of all their pharmacological effects: capillary-enhancing activity, antiphlogistic, antiallergenic, antimicrobial, antiviral activity [6-8].

In plants flavonoids are usually presented in the form of glycosides dissolved in cellular fluid, which is concentrated in vacuoles and fluoro- and chloroplasts, i.e. in cell volume. During extraction, they need to overcome resistance of boundary diffusion layer, whereas process is performed by maceration. Taking into account all three stages it is reasonable to write an equation for determination of total mass-transfer resistance during maceration as:

$$
\frac{1}{k}=\left(\frac{\delta}{D_{c}}+\frac{d}{D_{m}}+\frac{\varepsilon}{D_{e}}\right)
$$

where $D_{c}-$ diffusion coefficient through the cell membrane, $\mathrm{m}^{2} / \mathrm{s} ; D_{m}$ - diffusion in the extracellular environment, $\mathrm{m}^{2} / \mathrm{s} ; D_{e}$ - coefficient of molecular diffusion in extraction solvent volume, $\mathrm{m}^{2} / \mathrm{s} ; \delta$ - thickness of cell membranes, $\mathrm{m} ; d$ - diameter of particle of solid, $\mathrm{m} ; \varepsilon-$ porosity of plant material layer.

According to diffusion layer theory, where molecular diffusion takes place and concentration of target substance is strongly expressed, the thickness of boundary layer depends on extractant moving velocity, coefficient of diffusion of liquid kinetic viscosity. Under turbulization of liquid flow the thickness of diffusion layer decreases, consequently a resistance of convective mass 
transfer can be disregarded under the circumstances of mixing. This is fundamental when it comes to determination of mass transfer coefficients through cell membrane and mass conductivity in intercellular environment. From this perspective Eq. (1) takes the form:

$$
\frac{1}{k}=\left(\frac{\delta}{D_{c}}+\frac{d}{D_{m}}\right)
$$

According to this thesis main kinetic constants were determined in Ref. [1, 2].

With account of rearrangement of Eq. (1) for determination of total value of mass transfer resistance coefficient it can be written as:

$$
\frac{1}{k}=\left(\frac{1}{k_{c}}+\frac{1}{k_{m}}+\frac{1}{k_{e}}\right)
$$

where $k$ - total mass transfer coefficient, $1 / \mathrm{s} ; k_{c}$ - mass transfer coefficient through the cell membrane, $1 / \mathrm{s} ; k_{m}-$ coefficient of mass conductivity in intercellular environment, $1 / \mathrm{s} ; k_{e}$ - coefficient of mass conductivity in extractant, which is in free volume of layer of extracted material, $1 / \mathrm{s}$.

\section{Experimental}

Investigation of extraction kinetics of exhausted material of hops strobiles was conducted by maceration in stationary layer of extractant during $24 \mathrm{~h}$.

For this, $10 \mathrm{~g}$ of extraction cake of plant material sample was loaded into 0.21 container, together with 0.11 of extractant. Phase ratio (solid:liquid) was $\mathrm{S}: \mathrm{L}=1: 10$. Previously, by sieve analysis, the size of fragmented material was determined. Following distribution of material to fractions was provided: $1 \cdot 10^{-3} ; 2.5 \cdot 10^{-3} ; 5 \cdot 10^{-3} ; 7 \cdot 10^{-3}$ and $9.5 \cdot 10^{-3} \mathrm{~m}$. Extraction process was conducted by maceration at $293 \pm 2 \mathrm{~K}$. For eliminating polyphenols $50 \%$ alcohol was used as extractant, for the extraction of flavonoids sum a water-ethanol mixture $(70 \%)$ was used. Under several periods of time (Fig. 1) the content of each container was sequentially amalgamated, filtered and analyzed.

During extraction by maceration the extractant volume is lower than that during mixing extraction. For "mirror" effect of extractant over extraction cake in our case for 1 part of material comes 10 parts of extractant. In stationary layer of extractant molecular diffusion of target substances takes place from phase boundary to main volume of extract.

For determination of total mass transfer coefficient math expression of investigated process [9] can be written as:

$$
\left\{\begin{array}{l}
W \cdot \frac{d C_{1}}{d t}=k \cdot F \cdot\left(C_{1 n}-C_{1}\right) \\
W \cdot\left(C_{1 p}-C_{01}\right)=G \cdot C_{c 0} \\
t=0 ; C_{01}=0 ; C_{c}=C_{c 0}
\end{array}\right.
$$

where $G$ - weight of extracted plant material, $\mathrm{kg} ; W-$ volume of extractant, $\mathrm{m}^{3} ; C_{1 n}$ - concentration of target substance at the particle surface of solid phase, $\mathrm{kg} / \mathrm{m}^{3}$; $C_{1}$ - concentration of target substance in main volume of extract; $C_{1 p}$ - equilibrium concentration, $\mathrm{kg} / \mathrm{m}^{3} ; C_{01}-$ initial concentration of target substance in extractant, $\mathrm{kg} / \mathrm{m}^{3} ; F-$ area of mass transfer surface, $\mathrm{m}^{2} ; C_{c 0}-$ concentration of target substance, $\mathrm{kg} / \mathrm{m}^{3}$.

As a result of solving simultaneous equations (4) occurs:

$$
\begin{aligned}
& \left(1-\frac{C_{1}}{C_{1 p}}\right)=A \cdot e^{-k t} \\
& k=\frac{D_{e} \cdot F}{W \cdot 0.5 l}
\end{aligned}
$$

where $D_{e}$ - coefficient of molecular diffusion in extraction solvent, $\mathrm{m}^{2} / \mathrm{s} ; l$ - distance between material particles, $\mathrm{m}$; $F$ - area of mass-transfer, $\mathrm{m}^{2}$.

After taking the logarithm of Eq. (5) it is deduced:

$$
\ln \left(1-\frac{C_{1}}{C_{1 p}}\right)=\ln A-k t
$$

In coordinate system we find the value of $k$ as a slope ratio of right line (Fig. 2). For the calculation of diffusion coefficient of polyphenols and flavonoids in extractant layer $D_{e}$ we use Eq. (6).

$$
D_{e}=\frac{k_{e} \cdot W \cdot 0.5 l}{F \cdot \varepsilon}
$$

From Eq. (3) we find coefficient $k_{e}$ :

$$
\frac{1}{k_{e}}=\left(\frac{1}{k}-\frac{1}{k_{m}}-\frac{1}{k_{c}}\right)
$$

Area of mass transfer $F$ was found by making assumption that particles have a shape of disk, inasmuch as for determination of particle size sieve with round opening was used, then:

$$
F=\pi \cdot r^{2}+h \cdot L
$$

where $L$ - length of circle, $\mathrm{m} ; r$ - particle radius, $\mathrm{m} ; h-$ particle thickness determinate experimentally, $\mathrm{m}$.

For determination of general quantity of extracted particles we use porosity of plant material layer $\varepsilon$, which is determined as:

$$
\varepsilon=\frac{d_{0}-d_{t}}{d_{0}}
$$

where $d_{0}$ - volumetric density of extraction cake, $\mathrm{kg} / \mathrm{m}^{3}$; $d_{t}-$ tap-density of extraction cake, $\mathrm{kg} / \mathrm{m}^{3}$.

Trustworthiness of the process mathematical descriptions and obtained results was confirmed by theoretical calculation of diffusion coefficient of polyphenols and flavonoids in extractant applying Eq. (12) [10], in case of using solvents and extractants, specified above, when extracting hops strobile extraction cake. 


$$
D=\frac{K T}{\mu_{2} \cdot V_{1}^{1 / 3}}
$$

Coefficient of molecular diffusion depends on temperature and dynamic viscosity of extractant. Molar volume of target substance was calculated according to [11].

$$
K=8.2 \cdot 10^{-8}\left(1+\frac{3 V_{2}}{V_{1}}\right)^{2 / 3}
$$

where $K$ - coefficient calculated by Eq. (13); $T$ temperature, $\mathrm{K} ; \mu_{2}$ - dynamic coefficient of viscosity of extractant, $\mathrm{cPa} ; V_{l}-$ molar volume of dissolved substance, $\mathrm{cm}^{3} / \mathrm{mol} ; V_{2}-$ molar volume of extractant, $\mathrm{cm}^{3} / \mathrm{mol}$.

\section{Results and Discussion}

The results of experimental studies on the kinetics of extracting from hops strobiles extraction cake by maceration are presented in Fig. 1 as eliminated flavonoids concentration vs. time. As one can see from the figure, the highest possible concentration value $\left(0.060 \mathrm{~kg} / \mathrm{m}^{3}\right)$ is obtained most quickly $(8450 \mathrm{~s})$ for the particles with the size of $1 \mathrm{~mm}$. Thus, herbal raw material particle size significantly influences the velocity of target substance yield. With the increase of herbal raw material diameter the time of equilibrium achievement increases. This is due to the point that with the enlargement of herbal raw material particle size itinerary of target substances diffusion from intercellular environment to interphase boundary increases.

Solution of mathematical model $[1,9]$ allows to determine value of diffusion coefficient through the cell membrane and in intercellular environment with intensive mixing or upon condition of intensive hydrodynamics. Calculation formulas look like [1]:

$$
k_{c}=\frac{D_{c} F_{c}}{\delta_{c} V_{c}}=\frac{D_{c}}{\delta_{c} R_{e q}}
$$

where $R_{\text {eq. }}$ - equivalent radius, $\mathrm{m}$.

$$
k_{m}=\frac{D_{m} F_{m}}{l V_{m}}=\frac{D_{m}}{d R_{m}}
$$

where $R_{m}$ - brought radius, $\mathrm{m}$.

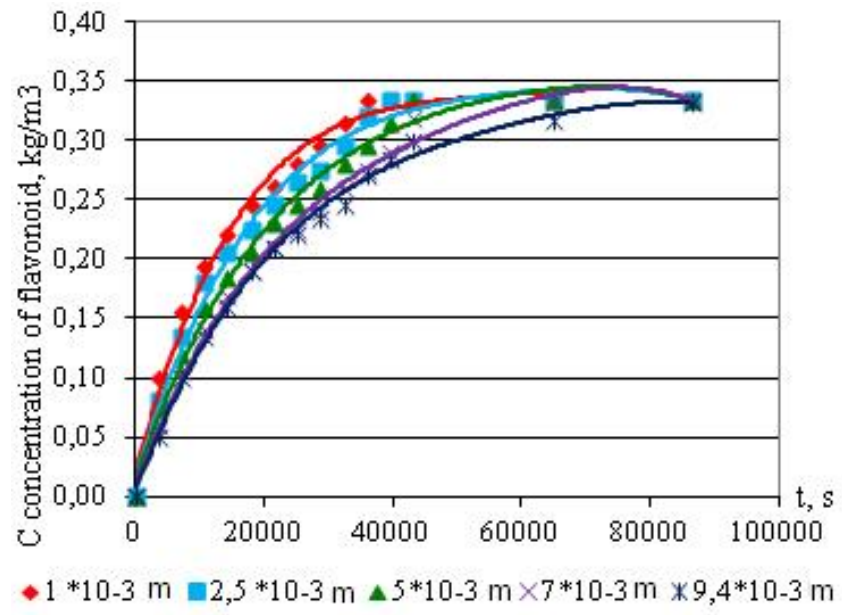

Fig. 1. Dependence of the flavonoids concentration on time during extraction by $70 \%$ water-ethanol mixture of hops strobile extraction cake, fragmented to different sizes

Based on experimental data of flavonoid extraction from hops strobiles extraction cake, which were reduced to established size under mixing in Ref. [2], the mass transfer coefficients through the cell membrane and in intercellular environment were determined, conforming to diffusion coefficient through the cell membrane $D_{c}$ and in intercellular environment $D_{m}$ for hops strobile extraction cake, which are $10^{-14}$ and $10^{-11} \mathrm{~m}^{2} / \mathrm{s}$. Results of calculation are presented in Table 1 . On the basis of the obtained experimental data (Fig. 1) the dependencies $\ln \left(1-C_{I} / C_{l p}\right)=f(t)$ were built. These dependences are linear and give opportunity to determine leaching coefficient and total mass-transfer resistance for each value of the particle size of the solid phase from $1 \cdot 10^{-3}$ to $9.4 \cdot 10^{-3} \mathrm{~m}$. These dependencies, approximated with linear functions for extraction process of flavonoids, are presented in Fig. 2.

Table 1

Estimated and experimental values of kinetics of flavonoid extraction $70 \%$ from reduced hops strobiles with water-ethanol mixture in tank with mixer

\begin{tabular}{|c|c|c|c|c|c|}
\hline$d \cdot 10^{3}, \mathrm{~m}$ & $k \cdot 10^{4}, 1 / \mathrm{s}$ & $k_{c} \cdot 10^{4}, 1 / \mathrm{s}$ & $k_{m} \cdot 10^{4}, 1 / \mathrm{s}$ & $D_{c} \cdot 10^{14}, \mathrm{~m}^{2} / \mathrm{s}$ & $D_{m} \cdot 10^{11}, \mathrm{~m}^{2} / \mathrm{s}$ \\
\hline 1 & 3.5 & 3.48 & 6.98 & 1.00 & 6.94 \\
\hline 2.5 & 3.0 & 3.48 & 6.48 & 1.00 & 6.98 \\
\hline 5 & 2.6 & 3.48 & 6.08 & 1.00 & 7.13 \\
\hline 7 & 2.4 & 3.48 & 5.88 & 1.00 & 6.97 \\
\hline 9.4 & 2.2 & 3.48 & 5.68 & 1.00 & 7.03 \\
\hline
\end{tabular}


Kinetic constants of the process of flavonoids extracting by maceration with $70 \%$ water-ethanol mixture from hops strobiles extraction cake reduced to certain sizes

\begin{tabular}{|c|c|c|c|}
\hline$d \cdot 10^{3}, \mathrm{~m}$ & $k \cdot 10^{5}, 1 / \mathrm{s}$ & $A$ & $\begin{array}{c}\text { Equation of dependence of target substance concentration with time for } \\
\text { sufficient diameter }\end{array}$ \\
\hline 1.0 & 6.8 & 0.894 & $C_{1}=0.335\left(1-0.894 e^{-6.8 \cdot 10^{-5} t}\right)$ \\
\hline 2.5 & 5.7 & 0.900 & $C_{1}=0.335\left(1-0.900 e^{-6.7 \cdot 10^{-5} t}\right)$ \\
\hline 5.0 & 4.9 & 0.910 & $C_{1}=0.335\left(1-0.910 e^{-4.9 \cdot 10^{-5} t}\right)$ \\
\hline 7.0 & 4.2 & 0.925 & $C_{1}=0.335\left(1-0.925 e^{-4.2 \cdot 10^{-5} t}\right)$ \\
\hline 9.4 & 4.1 & 0.948 & $C_{1}=0.335\left(1-0.948 e^{-4.1 \cdot 10^{-5} t}\right)$ \\
\hline
\end{tabular}

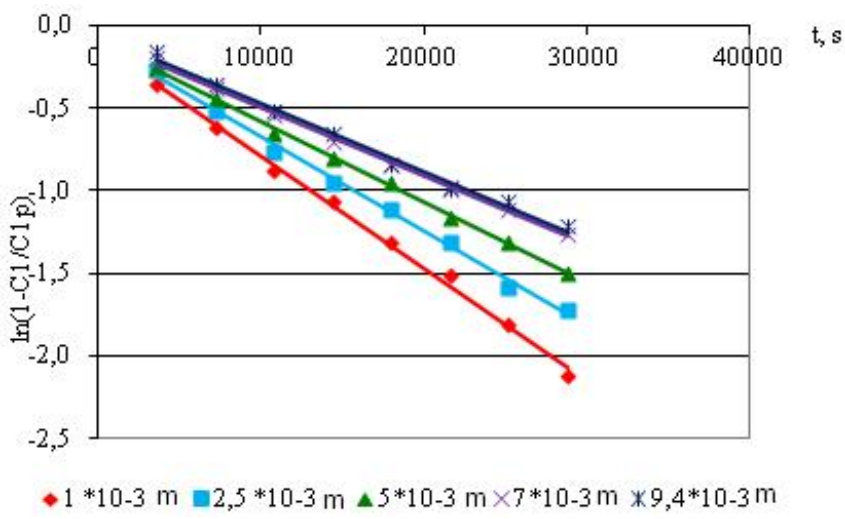

Fig. 2. The logarithmic dependence of the flavonoids concentration on time during extraction by $70 \%$ water-ethanol mixture of extraction cake of hops strobile, fragmented to sizes

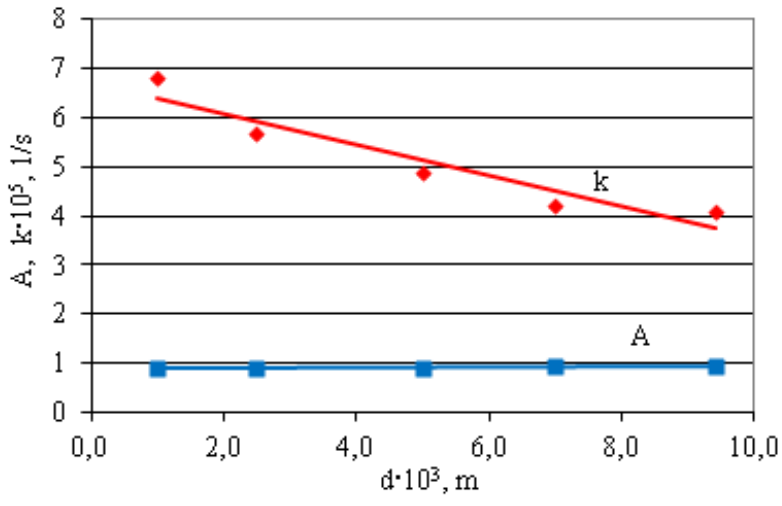

Fig. 3. Dependency of mass transfer coefficient $k$ and leaching coefficient $A$ upon particle size $d$ in flavonoid extraction process by maceration with $70 \%$ water-ethanol mixture from hops strobile extraction cake

Table 3

Information values for calculation of molecular diffusion coefficient for flavonoids in water-ethanol mixture in terms of hyperosid

\begin{tabular}{|c|c|c|c|c|c|}
\hline$T, \mathrm{~K}$ & $\mu_{2}, \mathrm{cPa}$ & $V_{1}, \mathrm{~cm}^{3} / \mathrm{mol}$ & $V_{2}, \mathrm{~cm}^{3} / \mathrm{mol}$ & $K \cdot 10^{7}$ & $D, \mathrm{~m}^{2} / \mathrm{s} \cdot 10^{8}$ \\
\hline 293 & 2.01 & 413.38 & 59.20 & 1.04 & 7.45 \\
\hline
\end{tabular}

Based on these dependencies a system of equations for the process of flavonoids extracting is obtained:

$$
\left\{\begin{array}{l}
k_{1}=-0.000068 \cdot t-0.11179 \\
k_{2}=-0.000057 \cdot t-0.10525 \\
k_{3}=-0.000049 \cdot t-0.09422 \\
k_{4}=-0.000042 \cdot t-0.07808 \\
k_{5}=-0.000041 \cdot t-0.05306
\end{array}\right.
$$

where $k_{1-5}=\ln \left(1-\frac{C_{1}}{C_{1 p}}\right)$.

The system of equations (16) describes approximated logarithmic straight lines in the second period of extraction process by maceration, which enables to determine the mass transfer coefficients and leaching coefficients. Thus determining mass transfer coefficients and leaching coefficients during polyphenols extraction we obtain an opportunity to describe the change in extractant concentration with time through mathematical expression for each solid phase particle size (Table 2).

For known values of mass transfer coefficients for each solid phase particle size we build dependency $k_{i}=f(d)$ and $A=f(d)$ (Fig. 3).

The obtained result further allow to write an analytical expression (17). As can be seen from Fig. 3, the total value of flavonoids mass transfer coefficient is described by linear dependence (18) within the studied sizes.

$$
k=-0.3178 \cdot 10^{-5} \cdot d+6.7228 \cdot 10^{-5}
$$


Analogically dependence of leaching coefficient A upon solid phase particle size is obtained and is described by Eq. (18):

$$
A=0.0064 \cdot d+0.8842
$$

As a result, total equation of kinetics of flavonoids extraction from extraction cake of hops strobile is:

$$
C_{1}=(0.0064 d-0.8842) \cdot(1-\exp (-0.3178 d+0.6722) t(19)
$$

Considering the obtained results (Table 2) and following equation of total mass transfer resistance (9) it is now possible to determine $k_{e}=5.1 \cdot 10^{-4} 1 / \mathrm{s}$ and calculate period of coefficient of molecular diffusion $D_{e}$ for flavonoids in extragents taking into account experimental data according to (8) and compare its value with that calculated by the expression (12). The calculated value considering experimental data $D_{e}=1.15 \cdot 10^{-8} \mathrm{~m}^{2} / \mathrm{s}$.

Information values for determining of the flavonoids molecular diffusion coefficient, expressed as hyperosid, is shown in Table 3. The calculated from the expression (12) value $D_{e}$ is $7.45 \cdot 10^{-8} \mathrm{~m}^{2} / \mathrm{s}$ and has one period.

Thus, the value of the coefficient of flavonoids molecular diffusion is calculated on the basis of experimental data by formula (12) and have a period of $10^{-8} \mathrm{~m}^{2} / \mathrm{s}$, which verifies the mathematical description of extraction process from cellular structure solid bodies.

\section{Conclusions}

Mathematical dependences of the extraction kinetics of hop strobiles extraction cake are obtained with the reference to its anatomical structure, such as the availability of cellular and intercellular space that allow to identify the main kinetic coefficients of the process, its regime and predict the dynamics of biologically active compounds extraction in the implementation of extraction process in practice.

\section{References}

[1] Dyachok V., Ilkiv N.: Chem. Chem. Technol., 2013, 7, 23.

[2] Pavliuk I., Stadnytska N., Novikov V.: East.-Eur. J. Enterprise Technol., 2015, 5/11, 36 . https://doi.org/10.15587/17294061.2015.50965.

[3] Grodzinskiy A.: Likarski Roslyny: Encyclopedychnyi Dovidnyk. Olimp, Kyiv 1992

[4] Lyashenko M.: Biochimiia Chmeliu i Chmeleproductov. Polesye, Zhytomyr 2002.

[5] Van Dijk C., Driessen A., Recourt K.: Biochem. Pharmacol, 2000, 60, 1593. https://doi.org/10.1016/S0006-2952(00)00488-3.

[6] Cimbalist N., Stepanova T., Burdo A.: Pharmacy, 2005, 4, 12.

[7] Kovalyov V., Pavliy O., Isakova T.: Pharmacognoziia z

Osnovamy Biochimii Roslyn. Prapor, Kharkiv 2000.

[8] Lyashenko M., Mychajlov M., Galak G.: Kharchova ta Pererobna Prom., 2002, 12, 19.

[9] Dyachok V.: Chem. Chem. Technol., 2010, 4, 163.

[10] Akselrud G., Lisjansky V.: Extragirovanie Tverdoe TeloZhydkost. Khimiya, Leningrad 1974.

[11] Pavlov K., Romankov P., Noskov A.: Primery i Zadachi po Kursu Protsessov i Apparatov Khimicheskoi Promyshlennosti. Khimiia, Leningrad 1987.

Received: December 13, 2016 / Revised: J anuary 12, 2017 / Accepted: M ay 31, 2017

\section{КІНЕТИКА ЕКСТРАГУВАННЯ БІОЛОГІЧНО АКТИВНИХ СПОЛУК ЗІ ШРОТУ ШИШОК ХМЕЛЮ}

Анотація. Вивчена кінетики екстрагування флавоноїдів зі ироту ииток хмелю, визначено сумарне значення опору масоперенесення враховуючи анатомічні особливості рослинної сировини, а саме наявність клітинного та міжклітинного середовища. Підтверджено достовірність запропонованого математичного апарату для визначення головних кінетичних констант процесу. Отриманий результат можна застосовувати для розрахунку обладнання при проектуванні технологічних схем екстрагування твердих тіл клітинної будови.

Ключові слова: шишки хмелю, шрот, кінетика екстракиії, коефічієнт дифузї, коефіиієнт масоперенесення. 